\title{
The Quiet Crisis in
}

\section{Government Publishing}

\begin{abstract}
Although the publishing activities of the federal government comprise the most extensive information distribution system in the world, they fall far short of meeting the "information requirements of a highlyeducated, industrialized, complex, and space-age society." Enormous amounts of money are spent annually on printing-some in the GPO, and much outside it-and there is considerable bureaucratic battling over what branch or agency receives priority in getting its publications into print. Documents are sometimes sold and often deposited, but the depository system is so uncomprehensive in scope and so costly to administer in the recipient libraries as to make it at best a mixed blessing. High level attention is badly needed.
\end{abstract}

${ }^{667}$ he United States government is the biggest publisher in the world."

This statement, or variations on the same theme, is encountered frequently in the speeches and writings of government officials, librarians, scholars, and others whose work causes them to have an interest in federal government publications. The connotations are not always positive. Occasionally, a legislator will arise in wrath on the floor of Congress, assail the bureaucrats as a bunch of paper pushers, regale his colleagues with quotations from the latest absurdity emanating from the government presses, such as "The Official Girlwatcher's Manual," 1 and urge a massive cut in printing

${ }^{1}$ Congressional Record, September 13, 1963, p. 16955. The Girlwatcher's Guide was not a government publication, but a citation to it was buried in an 814-page bibliography of programed instruction

Mr. Brock is Chief, Business Administration and Social Sciences Division, University of North Carolina Library. This article is preprinted from a book to be published soon by the Public Affairs Press, edited by M. B. Schnapper, concerning government information policies and practices. appropriations. Whether meant negatively or positively, however, the statement implies an enormous government publishing program, with books, pamphlets, and periodicals on every conceivable subject being produced by the thousands and distributed widely throughout the land.

That there is much truth in this picture may be seen from a few figures on the government's printing and publication distribution operations during fiscal year 1963:

1. The Government Printing Office produced \$127.1 million worth of printed matter, resulting in a total production of 1,022,840,498 copies of publications.

2. The Public Documents Division of GPO sold 53,076,581 copies of publications, with total sales receipts of $\$ 11,297,784.06$.

3. The Public Documents Division made free distribution of 5,817,058

materials produced on contract with the U.S. Office of Education. The incident is significant primarily as an example of Congressional ingenuity in needling the executive bureaucracy. 
copies of publications to more than six hundred libraries across the country.

These figures, moreover, as will be seen below, represent only a part of the government's investment in printing and publishing. Despite this seemingly enormous effort, the contention here will be that the government's program of printing, publishing, and distribution of publications is seriously deficient when measured against the information requirements of a highly-educated, industrialized, complex, and space-age society. There are, moreover, not one but several government publication and distribution programs, and they overlap and intersect in a tangle of administrative and operating confusion beside which the much-criticized administration of the foreign aid program is a model of rationality and efficiency. There is, in fact, a "quiet crisis" in government publishing which has almost completely escaped attention, both within and without the government.

In attempting to analyze this crisis below, the focus is on two sets of questions:

1. How much does the government spend on printing and publishing? What has been the pattern of this expenditure in recent years? What proportion of the total federal budget goes for printing and publishing? Is this level of expenditure adequate for present-day needs?

2 . Whatever the answer to these questions, taking the present government publications output as given, what happens to these publications? To what extent, and under what conditions, are they available to the general public, libraries, scientists, and others who have a legitimate need for the information contained in government publications?

\section{Extent of Government Publishing}

It is a fairly simple matter, using statistical data compiled by the government, to find such esoteric bits of information as the annual receipts of pool halls and bowling alleys in Great Falls, Montana ( $\$ 695,000$ in 1963); the number of strapless or convertible brassieres shipped annually in interstate commerce $(12,864,000$ in 1964); or the number of four-month-old or older chickens in Sagadahoc County, Maine (there are $21,025)$. Given such plenty, it might seem no problem at all to find out how much the government spends for printing, how much of this goes for printing of publications rather than forms, stationery, etc., and how many publications the government issues each year. Such is not the case. The government does not compile this information in its massive statistical program, and officials who have offered estimates from time to time have stressed that their figures are largely guesswork. In its analysis of federal printing expenditures in 1954, for example, the Hoover Commissiondespite its great resources and vast authority-confessed that its figures were only "rough estimates."2

In attempting to assess over-all government expenditures for printing, however, we do have two estimates whichwhatever their shortcomings-at least were arrived at by strictly comparable methods. One is the Hoover Commission estimate mentioned above, the other a summary of 1964 expenditures prepared by the Budget Bureau at the author's request.

The Hoover Commission, using the line item labeled "printing and reproduction" in the federal budget for fiscal year 1954, placed total government printing expenditures at $\$ 370$ million. $^{3}$ The Budget Bureau, using the same line item of the budget for fiscal 1964, placed the total expenditure for that year at $\$ 274$ million. ${ }^{4}$ Thus we have what appears to be an incredible bu-

\footnotetext{
${ }^{2}$ Commission on Organization of the Executive Branch, Business Enterprises (Washington: GPO, 1955), p. 101.

Ibid.

4 Letter from Chief of Budget Preparation, Bureau of the Budget, February 23, 1965.
} 
reaucratic fact: government printing expenditures decreased by $\$ 96$ million, or 26 per cent, during a decade when total government expenditures were increasing by 46 per cent.

One other estimate, moreover, allows us to pinpoint the years during which this most non-Parkinsonian situation occurred. In 1960 the staff of the Congressional Joint Committee on Printing estimated total printing expenditures at $\$ 197.7$ million. $^{5}$ While this estimate apparently was arrived at by different methods than the other two, it is the most authoritative available and should be reasonably comparable. Accepting it, we find that during the eight years of the Eisenhower Administration, expenditures for printing decreased by $\$ 172.3$ million, or 47 per cent, while total federal expenditures were rising by 13 per cent.

Lest too many partisan implications be drawn from this analysis, however, the table below shows the pattern of printing expenditures as a percentage of total government expenditures during this century.

From this it is clear that the Eisenhower years were unique only in that the economy drives of that period resulted in an absolute decrease in the amount expended for printing.' Relative$l y$, however, the percentage of the fed-

\footnotetext{
s.S. Congress, House Committee on Appropriations, Legislative Branch Appropriations for 1962, Hearings, 87th Cong., 1st Sess. (Washington: GPO, 1961), p. 303 .
}

eral budget going for printing has been dropping drastically for decades, and the real bite came between 1940 and 1954, for which Democratic administrations must get the credit or take the blame. $^{6}$,

Is the present level of expenditure adequate? It will be obvious that the author is preparing to come down on the negative side of this question. Such a stance, of course, is almost un-American. Anyone who takes it is put into the position of arguing that the "paperwork jungle" of Washington should be increased rather than decreased. There are, moreover, no standards in this area. No one has devised an "optimum" ratio of government printing expenditures to total expenditures. Earlier ratios are hardly valid guides, since the range of goods and services produced by the government has changed too greatly. To take only the most obvious example, the budget for fiscal year 1900 did not have

\footnotetext{
- It should be noted that estimates of total printing expenditures made by the three sources-Joint Committee on Printing, the Hoover Commission, and the Budget Bureau-have differed considerably. The Hoover Commission put 1954 expenditures at $\$ 370$ million, while the Joint Committee staff put the 1955 figure at $\$ 165$ million. For 1964 the Budget Bureau offers an estimate of $\$ 274$ million, while the Joint Committee staff reports $\$ 235$ million for the same year. All figures purportedly represent "total printing expenditures" for the respective years. If the Joint Committee staff is right and the Hoover Commission is wrong, there would be no absolute decrease in printing expenditures during the Eisenhower Administration, as indicated above. On the other hand, the level of current expenditure would be lower. The discrepancies are perhaps most significant as an indication of the confusion and lack of accurate data in this area.
}

PERCENTAGE OF GOVERNMENT EXPENDITURES FOR PRINTING

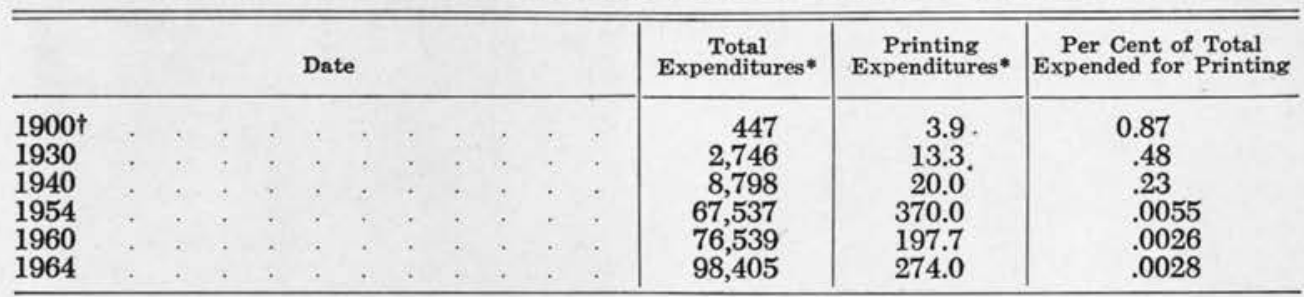

* In millions of dollars.

† Data for 1900 through 1940 taken from LeRoy C. Merritt, The United States Government as Publisher. (Chicago: University of Chicago Press, 1943) 
to accommodate millions for military hardware and billions for moon shots. Thus the argument that present printing expenditures are not adequate has to be made largely on a prima facie basis.

In attempting to make this case, and as background for analysis of problems of publication distribution, it is necessary to go into some detail on the physical and administrative aspects of government printing.

\section{The Government Printing Office}

According to the United States Code, "All printing, binding, and blank-book work for Congress, the Executive Office ... and every executive department, independent office, and establishment of the government, shall be done at the Government Printing Office." The law then provides for certain exceptions which, as will be seen below, have resulted in the establishment of not one but more than three hundred and forty government printing plants.

During fiscal year 1963 the GPO produced a total of \$127.1 million worth of printed matter. Analysis of the Annual Report of the Public Printer shows that $\$ 70$ million of this (or 55 per cent) went for publications, the rest for forms, notices, postal cards, and other miscellaneous printing. An additional $\$ 5.2$ million of printing was done in six field plants of the GPO located in New York, San Francisco, and other cities. Reports do not allow a breakdown of this amount between publications and other printing. Assuming that the ratio was the same as for the main GPO plant, however, we have an additional $\$ 2.9$ million for publications, giving a total of $\$ 72.9$ million.

Unfortunately, it is impossible to translate expenditures for publication printing into number of publications produced.'The GPO, reflecting its orientation as "printer" rather than "publisher," reports the number of copies of publications printed, and even the number of pages, but not the number of different publications or titles.
Administratively, GPO is a creature of Congress, not of the executive branch, and is specifically under the supervision of the Congressional Joint Committee on Printing, which consists of three Senators and three Representatives. Legally, the President appoints its chief officer, the Public Printer, but actually the Joint Committee governs the appointment (the present Public Printer was formerly staff director of the Committee) and the President exerts no control whatever over GPO operations. This curious administrative structure has long intrigued students of government and occasioned some criticism. In 1912 Senator Elihu Root noted:

The GPO is not in any executive department and has no supervision, except the supervision of Congress. . . . Now, either Congress ought to make its own supervision adequate, if it is going to perform that duty, and create for it adequate machinery and fix upon somebody the responsibility, or else it ought to put this bureau in an executive department. Whichever Congress chooses to do is all right, but the office is today a lost child, and has been ever since I have known anything about the administration of the Government of the United States. ${ }^{7}$

This administrative pattern may have been justified a century ago. When Congress established the GPO in 1861 primarily in order to curb the graft and corruption which resulted from its previous practice of contracting out printing to private firms, the majority of government printing was done for Congress rather than the executive branch. Today, however, only 12 per cent of GPO printing is Congressional, the remaining 88 per cent being done for the various executive agencies. This anomolous administrative legacy of the nineteenth century, however, is a primary cause of the present government printing problems and of the great gaps in the government's system of publication distribution.

\footnotetext{
7 U.S. Government Printing Office, 100 GPO Years, 1861-1961 (Washington: GPO, 1961), D. 168.
} 


\section{Non-GPO Printing}

As noted earlier, the Government Printing Office in Washington actually is only one of more than three hundred and forty government printing plants scattered across the country and overseas. The non-GPO plants, called "departmental" or "field" plants, are run by the various executive departments, agencies, bureaus, commissions, etc., and are completely unrelated to GPO.

The development of these plants is part of the long and complex history of centralization versus decentralization of government printing, which need not be covered here. It is enough to say that they developed primarily as the result of the vast expansion of the executive branch under the impact of the New Deal, World War II, the Cold War, and the Space Age. Although other factors were present, they were authorized essentially because the GPO did not have the capacity to handle the tremendous executive branch printing requirements which stemmed from this growth.

While precise figures are available for the amount of printing produced through GPO, no one really knows how much printing is done in the non-GPO plants. In 1954 the Hoover Commission noted:

The total cost of printing done in these plants in the executive branch can only be guessed at. Estimates run from $\$ 100$ million to $\$ 350$ million annually. One government official estimated the expenditure at $\$ 250$ million, another official as high as $\$ 350$ million annually. Both officials were familiar with government printing expenditures.

The most authoritative current estimate of non-GPO printing is made by the staff of the Joint Committee on Printing. For fiscal year 1963, this source put the total at $\$ 106.4$ million. $^{8}$ Combined with the GPO total of $\$ 127.1 \mathrm{mil}-$ lion, this would mean that 46 per cent of

\footnotetext{
8 "Staff Report to the Joint Committee on Printing," April 1964 (mimeographed).
}

all government printing for fiscal year 1963 was done outside GPO.

We found that 55 per cent of GPO expenditure went for publications rather that other printing. If this ratio is applied to non-GPO printing, we would have $\$ 58.5$ million going for "publication printing" in non-GPO plants. Given the $\$ 72.9$ million for publication printing by GPO, this would mean that 44 per cent of government publications are produced outside the Government Printing Office. There is considerable evidence, however, that because of the differences in types of printing involved, the ratio is much higher in the non-GPO plants. In 1962, for example, the staff director of the Joint Committee on Printing estimated that from 60 to 65 per cent of all government publications were produced outside GPO. ${ }^{9}$ The matter is of some importance in the analysis of publication distribution programs below. In order to have a base from which to analyze distribution, we will split the difference in these figures and assume that 55 per cent of all government publications are printed in the non-GPO plants.

It was noted above that the three hundred and forty-odd non-GPO printing plants were run by the various executive agencies and were unrelated to GPO. Though technically true, in operational terms this is a very misleading picture; these plants actually are under very tight Congressional control. The legal basis for this control is found in a 1919 law which empowers the Congressional Joint Committee on Printing "to adopt and employ such measures as, in its discretion, may be deemed necessary to remedy any neglect, delay, duplication, or waste in the public printing and binding and the distribution of government publications." Under this broad power the Joint Committee authorizes (and abolishes) non-GPO plants and regulates their operation down to the

'U.S. Congress, Senate Committee on Rules and Administration, Depository Libraries, Hearings, 87th Cong., 2nd Sess. (Washington: GPO, 1962), p. 21. 
smallest detail, such as requiring committee approval before any plant can buy a "power operated paper cornering machine."10

These factors provide sufficient background for an analysis of the curious pattern of government publishing, the most significant aspect of which is Congressional manipulation and tight control over executive publishing.

\section{The Congressional "SQueEze" oN Government Publishing}

From the reports of the Public Printer and the Joint Committee on Printing, we know that only $\$ 15.2$ million of the total government printing bill for fiscal 1963 was expended for Congressional printing. This leaves $\$ 218.3$ million, or 94 per cent, for printing by the various executive departments and agencies. At first glance this looks like another example of the "swollen executive bureaucracy" which Congressmen frequently complain about. Considering the fact that total expenses for Congress constituted less than one-fiftieth of one per cent of total federal expenditures for 1963 , however, it is evident that Congress-with its six per cent of printing expenditures-does not lack means of expression through the printed word.

The money for Congressional printing is appropriated directly to the Government Printing Office, and all Congressional printing is done at GPO. Executive agencies, theoretically at least, may have their printing done at GPO or in their own departmental and field plants. ${ }^{11}$ In either case the cost must be paid from their appropriation for "printing and reproduction." The agencies prefer to route most printing to their own plants, for reasons of cost and administrative control.

\footnotetext{
${ }^{10}$ U.S. Congress, Joint Committee on Printing, Government Printing and Binding Regulations, April 1,1968 , p. 8 .

II The executive agencies may contract out some printing to commercial printers, just as GPO also does, but the amount is limited and strictly controlled by the Joint Committee.
}

The comparative cost of GPO versus executive plant printing apparently has never been investigated. The only hard data on this question known to the author cropped up accidently in 1956 incidental to a House committee study of government paperwork. From data submitted to the committee by the Navy Department, we find that 18 per cent of Navy printing in 1956 was done at GPO, 80 per cent was done in Navy printing plants, and 2 per cent was done on contract by commercial printers. The 18 per cent of GPO printing, however, accounted for 54 per cent of the total Navy printing bill for the year. The 2 per cent of commercial printing accounted for 30 per cent of the cost, and the 80 per cent done by Navy plants constituted only 16 per cent of total cost. ${ }^{12}$

The great cost differential shown here does not mean that GPO is inefficient or that its charges are excessive. The problem lies primarily in the type of printing done in GPO as contrasted with the executive plants. Most GPO printing is by traditional letterpress methods, which are far more costly than the various offset or lithographic methods developed in the last thirty-odd years. GPO has begun to shift a bit recently toward the more modern methods, but it has been very slow to make the change, while very little of the printing done in the newer executive plants is by letterpress. The resulting cost differential gives executive agencies a strong motivation for attempting to avoid GPO. ${ }^{13}$

Considerations of time and administrative control point in the same direction. Congress is GPO's boss, and Congressional printing takes precedence. As

12 U.S. Congress, House Committee on House Administration, Paperwork Management and Printing Facilities in the United States Government, Part II, Report No. 2945, 84th Cong., 2nd Sess. (Washington: GPO, 1956), p. 130.

${ }^{13}$ In fairness to GPO, it should be noted that GPO officials, while partially admitting the existence of a cost differential, claim that the cost of printing in executive agencies is underestimated because certain factors are not figured in. 
the Public Printer put it in testimony before the House Appropriations Committee, "the Printing Office was established primarily to serve the needs of Congress and this will always be our first consideration." ${ }^{14}$ GPO officials have also testified that printing the Congressional Record is their "single most important job." The amazing job done on the Record under very difficult conditions probably makes it the world's prime example of printing speed and efficiency. At $\$ 98.00$ a page, of course, the Record also is undoubtedly the most expensive printing job of its magnitude in the world.

This emphasis on Congressional printing naturally means that printing for the executive agencies frequently is given short shrift. The Agricultural Research Service, for example, reported that the "average printing time" for its publications done by GPO was three to six months, while the average time in its own printing facility was one to two months. ${ }^{15}$ One agency official with several years' experience related to printing is convinced that a print priority list exists in GPO, "on which the Congress is at the top, the President is a poor second, and the rest of us are low men on the totem pole." Such factors tend to force executive printing into non-GPO plants, in which the agencies can set their own priorities.

Thus a quiet bureaucratic war goes on over the placement of executive branch printing. The referee in this war is the Joint Committee on Printing, and the executive agencies fight a losing battle. As background here, it is necessary too to note that GPO originally was set up to handle all government printing, and it did so until roughly the 1930 's. During those years and since the GPO built up far more capacity than was

\footnotetext{
14 Legislative Branch Appropriations for 1962, p. 293.

${ }^{15}$ John I. Thompson and Co., Study of the Federal Government's System for Distributing Its Unclassified $R \& D$ Reports, p. B-8. (A report done on contract for the National Science Foundation, 1962.)
}

needed to handle Congressional printing but insufficient capacity to perform all executive printing. Since the 1940's there has been a fluctuating ratio of GPO to executive plant printing, with the primary determinant being the printing capacity of GPO. Without going into all the details, it is sufficient to say that today, by controlling the number and size of non-GPO plants and the amount and kind of printing or reproduction they can perform, the Joint Committee acts as a traffic cop ensuring that sufficient executive printing goes to GPO to keep it operating at capacity.

At the same time, the Budget Bureau and the Congressional appropriations power operate to keep down over-all printing expenditures. The line for "printing and reproduction" is about the most friendless item in the budget. There are no extra-governmental lobbies working in its favor, and the Budget Bureau and department heads like it no more than Congressmen. Congressional committees usually leave it alone when making appropriations cuts, probably because it is so small compared with other budget lines, but the Budget Bureau and department chiefs tend to focus on it when Congress forces them to make across-the-board cuts.

\section{Over-all EfFect of Congressional Pressure}

This tight control over executive printing goes far toward explaining why the ratio of printing expenditures to total federal expenditures has dropped so dramatically since 1900 . So far as publications are concerned, this has meant that much informational, educational, and research material generated in the executive agencies has remained unpublished and unavailable outside of the filing cabinets of the agencies concerned. No doubt, as many might argue, it also has meant that much "trash" has been sidetracked. Such an argument, however, overlooks a crucial point which should 
be emphasized here, since this unpublished material automatically is excluded from the analysis of publication distribution below. The point is that an unknown but vast amount of time, effort, and money goes into generating this material, beside which the cost of printing it is fractional indeed. The Congressional pressure on executive printing simply creates a dam which stops the flow of significant information, as well as "trash," to a wider public. As former Senator Hubert Humphrey once put it, "I don't think it makes much sense to spend public funds' for research and then stash the results away." ${ }^{16}$

\section{Other Publishing Sources}

This analysis draws a somewhat unusual picture of Congressional success in frustrating the empire-building of the federal bureaucracy. While the analysis is believed to be accurate so far as it goes, the picture is incomplete. Congressmen have always suspected that the devious bureaucrats have been outwitting them, and to an extent they have. The executive agencies, caught between low printing appropriations and the Joint Committee-GPO squeeze described above, have devised at least three ways of cutting holes in the Congressional dam. All three, however, as will be seen below, have disastrous effects on publication distribution.

Office duplicating-Frequently agency and bureau personnel, rather than having something which they want to "get out" printed at GPO or in an agency plant, will simply stencil it and run off a few copies on the office mimeograph machine. $^{17}$

Contract research-Particularly within

\footnotetext{
${ }^{16}$ U.S. Congress, Senate Committee on Government Operations, Interagency Coordination of Information, Hearings, 87th Cong., 2nd Sess. (Washington: GPO, 1963), p. 4.

${ }^{17}$ Government Printing and Binding for the Fiscal Year 1955; Staff Report to the Joint Committee on Printing, 84th Cong., 2nd Sess. (Washington: GPO, 1956), D. 3.
}

the last ten to twenty years, most agencies have had large sums available for "contract research" to dispense to extragovernmental sources such as industrial firms, universities, and individuals. Almost all of this research results in publishable material, and the agency will require the contractor to furnish a certain number of copies, apparently ranging from 100 to over 1,000 in some cases, to be paid for out of his research grant. Thus in budget terms, printing costs are brought in under the prestigious umbrella of "research."

Publishing in the "open" literatureMany agencies also encourage their personnel, and particularly their contractors, to publish the results of their work in books or journals published commercially or by scientific societies. The $\mathrm{Na}$ tional Science Foundation has begun to subsidize a few scientific journals, and in 1962 the government adopted a policy which allows payment out of research contracts for "page charges" levied by private journals for publication of research findings.

\section{AvaIlablity and Distribution of Government Publications}

To what extent and under what conditions are publications emanating from these various sources-the Government Printing Office, non-GPO plants, etc.available to the general public, scientists, libraries, and others with a "need to know"?

Ideally, perhaps, one might argue that since the American taxpayer foots the bill, any publication not classified for security reasons ought to be available to him for the asking. To make such wholesale availability operational, however, would be prohibitively expensive and wasteful. The "average American" probably could not care less about 99.99 per cent of government publications. Judging by what is known of public demand, he is primarily interested in such 
items as a pamphlet on Infant Care issued by the Children's Bureau and the Internal Revenue Service's Your Federal Income Tax. At the other end of the spectrum, of course, there may be a scientist vitally interested in the most obscure and esoteric report emanating from a NASA contractor, or the large research library which needs government publications across the board and in great depth. There are no set standards for "availability and distribution," just as there is no simple measure of how much the government "ought to spend" on printing. The most that can be done is to examine the various levels and types of availability and distribution and point to problems resulting from the present chaotic government program.

\section{Sale of Government Publications}

The sales agent for government publications is the Superintendent of Documents, who heads the Public Documents Division of the Government Printing Office. The statistics on the Superintendent's sales program look impressive, and-given its rather narrow objectives-this probably is the most successful of the government's distribution programs.

In fiscal year 1963 over 53 million copies of publications were sold as the result of over 3 million orders, with sales receipts reaching an all-time high of $\$ 11.3$ million. A closer look, however, shows that only a small part of total publications output is available through this program. The Superintendent selects the publications he will offer for sale from among those produced through GPO, paying the Public Printer for the cost of printing extra copies for sale. Thus those publications emanating from any of the other sources described above automatically are excluded. No figures are available on the percentage of GPOproduced publications which the Super- intendent decides to offer for sale. His criterion for deciding, however, is that used by any good commercial publisher - "what will sell?"-and as he indicated to a Congressional committee, his selections "are on the conservative side."18 Thus the citizen can lay claim to only a small part of the publications his government produces by adding his pocket money to his tax money.19

As will be seen below, many other government publications can be obtained from other sources. In most cases, however, the citizen's access to them is not a matter of right, or even one of "paying his money and taking his choice." This study is concerned with very broad programs of availability and distribution and cannot cover specific "right to know" problems. In a democratic society, however, it is no insignificant matter that beyond this "purchase point" the citizen's access to government publications is largely at the discretion of government officials, and there have been many cases in which access was denied on very arbitrary grounds.

In recent years the sales program of the Superintendent of Documents has become a source of not inconsiderable profit for the government. In 1952, profits were $\$ 1.8$ million. In 1953 a change in computing the selling price of government publications resulted in price increases. ${ }^{20}$ An aggressive adver-

\footnotetext{
18 U.S. Congress, House Committee on House Administration, Sale and Distribution of Government Publications by the Superintendent of Documents, 84th Cong., 2nd Sess. (Washington: GPO, 1956), p. 12.

19 There are a few other sales sources for government publications, primarily the Office of Technical Services in the Commerce Department. The type and range of publications sold by these sources, however, is very limited, and the programs are minuscule compared to the sales program of the Superintendent of Documents.

${ }^{20}$ The precise results of this change are not clear, but in 1956 a Congressional committee staff member figured that the selling price of government publications was 125 per cent higher than the price paid for them by the Superintendent of Documents to the Public Printer. Even so, government publications are considerably cheaper than comparable commercial publications. See Sale and Distribution of Government Publications, p. 12.
} 
tising program began shortly afterward, and by 1963 profits had risen to $\$ 5.8$ million. While a few Congressmen have questioned the Superintendent sharply about "just how far-reaching the profit motive may be" within his office, ${ }^{21}$ the Superintendent actually is in a most unique and enviable position. Few government officials appearing before the House Appropriations Committee are greeted warmly as "our good friend who makes up that wonderful profit report."22 The matter would be of little moment, except for the fact that the desire to maintain and increase profits has cut into other and more important distribution programs.

\section{Free Distribution}

During $1963,90,980,823$ copies of publications were distributed free of charge for Congress and various executive agencies. Free distribution is made from publications produced through the Government Printing Office and is handled centrally by the Superintendent of Documents, who maintians 1,232 mailing lists containing 2,531,140 names for this purpose. The objective of this program is primarily to ensure that non-governmental "clienteles" receive publication of interest in their work. Examples would be a Federal Trade Commission mailing list to companies which might be affected by FTC regulations, or an Office of Education mailing list to presidents of colleges and universities.

Again, the statistics of the program look impressive, and it is the major program in which the government takes an initiative beyond statutory requirements to place relevant publications directly into the hands of those who might be expected to have a logical use for them. In recent years, however, free distribution has been cut back sharply, partly as a result of general economy drives

${ }^{21}$ Ibid., p. 2.

2 U.S. Congress, House Committee on Appropriations, Legislative Branch Appropriations for 1965, Hearings, 88th Cong., 2nd Sess. (Washington: GPO, 1964), p. 409 . but specifically in response to pleas from the Superintendent of Documents that it was undercutting his sales program. In 1947, for example, 91,972,607 copies of publications were distributed free; this constituted 27 per cent of the total GPO output of 340 million copies in 1947. The Superintendent of Documents, in reporting these figures, complained that "a large scale free distribution greatly nullifies our sales efforts" and noted that he was urging the agencies to curtail such openhandedness. ${ }^{23}$ Beginning in 1953, this drive was intensified and by 1958 had driven free distribution down to 62 million copies. By 1963, as noted earlier, the figure had climbed back to 90 million-presumably as the result of Democratic "giveaways"-but by this time represented only 9 per cent of the total GPO output of 1,022 million copies.

\section{Depostrory Library Distribution}

While there are many positive aspects to the sales and free distribution programs, whatever their limitations, from a long-range point of view they are largely wasted efforts; many of the publications so distributed will end up in the wastebasket and be of permanent use to no one. Recognizing the value of some program of distribution to libraries, which would maintain permanent collections of government publications and make them available to a wide range of users, Congress in 1857 passed legislation which provided for a system of "depository libraries" across the country. Though not officially labelled as such, this program appears to be the first example of "cooperative federalism," a general label attached to programs in which the federal government and the states join in a mutually useful endeavor.

In this case the mutual advantages are obvious. The libraries-and through them the public-receive material of

\footnotetext{
23 U.S. Government Printing Office, Annual Report of the Public Printer, 1947 (Washington: GPO, 1947), p. 214.
} 
great educational value, without which the research and educational efforts of the nation would be seriously hampered. The government meets at least in part the obligation incumbent upon a democratic government to provide for an "informed citizenry," supports education and research, and acquires agents who absorb demands which otherwise would increase the paperwork of Washington many times over.

By 1963 there were over six hundred depositories, located primarily in college, university, and public libraries, and the Superintendent of Documents was spending $\$ 757,000$ to distribute $5,817,000$ copies of publications to them. In this case the statistics can be misleading. The relatively low number of copies distributed, compared with the sales and free distribution programs, does not mean too much, since each library may receive only one copy of each publication. The expenditure, although only 27 per cent of the amount expended on the sales program, also means little for the same reason. The most logical criterion for this program is the proportion of total publications output which is available to the depository libraries.

Prior to 1962 , depository libraries were entitled to receive copies of only those publications which were produced through the Government Printing Office. In other words, the 55 per cent of publications identified earlier as being produced outside GPO were not available to them.

In recent years considerable controversy has arisen between government officials and the library profession over the "non-availability" of this major segment of government publications and in general over the respective obligations and contributions of each partner to the depository system. While the points at issue may seem obscure to the layman, they warrant some consideration here, since they reveal a pattern of governmental neglect and miserliness in con- nection with the distribution program which, in long-range terms, is the most significant.

The Superintendent of Documents, who administers the depository system, has complained that many libraries abuse the program by not providing adequate storage, maintenance, and service for their government publications collections, that many consider their depository status primarily as a matter of prestige, or as a way of "getting something for nothing." There is much truth in these charges. There have been cases in small libraries where shipments of government publications have remained unopened and unused, and in which the librarians haven't the foggiest idea of what to do with them.

Unfortunately, such cases of waste and abuse have diverted attention from the fact that many depositories serve as important links between government and the public, maintain large and well-trained staffs to service government publications, and spend far more on the depository program than the government itself. In 1955 a Congressional committee sponsored a survey of depositories which elicited data on how much they spent on servicing and maintaining their government publication collections. An analysis of replies from 368 depositories which answered the questionnaire shows that these libraries spent a minimum of $\$ 1,474,000$ in 1955 on service and maintenance of their collections. ${ }^{24}$ During the same year the government expended a total of $\$ 427,979$ on the entire depository program. ${ }^{25}$ Fifty-four large depositories, most of them in universities, spent over $\$ 10,000$ each for a total of $\$ 540,000$, over $\$ 100,000$ more than the government spent on all depositories. A conservative estimate today would be that many

\footnotetext{
${ }^{24}$ U.S. Congress, House Committee on House Administration, Revision of Depository Library Laws, Hearings, 85th Cong., 1st \& 2nd Sess. (Washington: GPO, 1958), p. 175.

${ }^{25}$ U.S. Congress, House Committee on Appropriations, Legislative Branch Appropriations for 1957, Hearings, 84th Cong., 2nd Sess. (Washington: GPO, 1956), p. 123.
} 
larger libraries are putting five or six dollars into the program for each dollar expended by the government to provide them with publications.

During the last two decades, moreover, the research and educational demands made upon these larger libraries have led them to seek access to the 55 per cent of publications output which was not available to them through the depository program. In 1946, working through the Association of Research Libraries, they set up and financed a Documents Expediting Project in an effort to acquire and distribute this mass of publications. This and other efforts, however, were only partially successful. By the mid-1950's the seriousness of the problem had filtered through to a few interested Congressmen, and in 1956 Rep. Wayne Hayes of Ohio succeeded in pushing through legislation in the House which would require that nonGPO publications be distributed to the depository libraries. The Senate did not act until 1962, when it passed similar legislation over the vigorous opposition of the Public Printer, the Superintendent of Documents, and many executive agencies.

"Authorization," of course, is a long way from "implementation," and in between stand the Congressional appropriations committees. The Superintendent of Documents, given responsibility for carrying out the legislation, in 1963 requested $\$ 175,000$ to begin implementation of what he described as a massive and complex program which might ultimately cost $\$ 2$ million a year. The latter figure apparently disturbed the House Appropriations Committee, as it may have been intended to do, and the committee refused to appropriate any money, directing the superintendent to study the matter further. In 1964 he returned with a proposal to begin the program by distributing the non-GPO publications of one department (Interior) and one bureau (Census) in another department. The committee approved the budget-busting sum of $\$ 57,000$ for this purpose, but warned that it would "want to evaluate the results against the cost and against the admittedly tremendous scope of the undertaking in the basic law before deciding future directions." 26

This is where the program stands today. Although a program once "on the books" is not likely to be dropped, this one is most unlikely to be pushed vigorously. There are serious obstacles to implementation of the legislation as it was written (although the program could be re-structured in such a way as to eliminate most of these $)^{27}$ and the Congress is not to be damned outright for wanting to go slow. The major obstacle, however, is a lack of knowledge, attention, and concern on the part of government officials. The government, which spends billions on an interstate highway program, putting in nine federal dollars for every state dollar, would do well to invest a few more dollars in a cooperative program in which it has a far better bargain.

\section{InTRA-GOVERNMENTAL CONTROL OF Publications}

So far we have been concerned with the distribution of government publications in multiple copies outside of Washington. Although the government has an obvious interest and obligation in this respect, some may question the arguments above that it should put far more effort and money into these distribution programs. There should be no question, however, that the government has an interest in seeing that at least one copy of each publication it issues is available centrally in Washington for internal use and for the historical record, if nothing else.

In order to accomplish this purpose,

\footnotetext{
${ }^{26}$ House Report 1307, 88th Cong., 2nd Sess., p. 17.

${ }^{n}$ See Clifton Brock, "Implementing the Depository Law," Library Journal, XC (April 1965), 1825-33.
} 
and to ensure a complete bibliographical listing of government publications, Congress passed a law in 1895 requiring that:

the head of each of the executive departments, bureaus, and offices of the Government shall deliver (to the Superintendent of Documents) a copy of each and every document issued or published by each department, bureau, or office not confidential in its character. (Italics added.)

For years there was disagreement, even among those in the best position to know, about whether this legal requirement was being observed. One Superintendent of Documents noted:

Many departments and agencies have within them divisions or offices which are separate publishers. Some of these activities are created by an administrative order of a government department. The people working in such offices have usually never heard of the Superintendent of Documents, much less of the requirement for furnishing him with a copy of all publications issued. ${ }^{28}$

One of his successors in the office, however, contended that "only a small number of public documents printed elsewhere than through the Government Printing Office" did not reach him. ${ }^{29}$

The matter apparently was settled by the 1956 survey of a House Subcommittee to Study Federal Printing and Paperwork. In its questionnaire to executive agencies, the subcommittee asked them to indicate if copies of "non-GPO" publications were being sent to the Superintendent of Documents, the Library of Congress, and the National Archives. The majority of agencies indicated that they did not supply copies to these agencies, and the subcommittee concluded that "the replies indicated general noncompliance" with the law. ${ }^{30}$

\footnotetext{
${ }^{28}$ Roy B. Eastin, "Central Indexing and Distribution of U.S. Government Publications," CRL, XV (January, 1954), 35.

${ }^{29}$ Sale and Distribution of Government Publications, p. 18.

${ }^{30}$ Paperwork Management and Printing Facilities, p. 24 .
}

Thus the government itself does not have a complete listing or collection of its publications, even in the Library of Congress. Its own internal distribution program, which one official described as "more like schoolboys trading marbles than like an efficient program," ${ }^{31}$ is-if anything-in more chaotic a condition than the external distribution programs. Analysis of these internal problems would require a separate study, but perhaps some of the flavor of the situation emerges from a characteristically vigorous statement made by former Senator Hubert Humphrey:

The plain fact is that the information situation in the executive branch and among federally supported contractors and grantees amounts to virtual chaos.

Information can be found-amidst this chaos-but to do so often requires a sizable, expensive, protracted search.

The search may prove so long that, in utter frustration, decisions are often made without adequate information, the quest for prior data is thus abandoned as not being worth the time and expense.

Not even the President of the United States could today-within a matter of hours or even a few days-find out what he would like to know. ${ }^{32}$

\section{Conclusion}

Forty years ago the printing, publishing, and publication distribution activities of the federal government were not a matter of general concern. The government was a negligible factor in the educational, industrial, and research efforts of the nation. Like Calvin Coolidge, its publishing program could remain relatively inactive and silent, and it did not matter much. But today, with the federal government financing three-fourths of the national research effort and moving swiftly into massive support of education, the negative effects of its chaotic (Continued on page 531)

э Depository Libraries, Hearings, p. 91.

32 Interagency Coordination of Information, p. 51. 
Ellsworth writes about school libraries, the reader may well take issue with his thesis that school libraries were moribund until the 1960's. The American Association of School Librarians' Standards for School Library Programs was based on levels found through research in good school libraries, yet Ellsworth seems to imply that until 1960 good school libraries were virtually nonexistent.

Ellsworth rightly criticizes the quality of the literature of school librarianship, but at the same time ignores important and influential documents. One publication of great import, and one that would have strengthened his case but which he has not mentioned, is Responsibilities of State Departments of Education for School Library Services; a Policy Statement issued by the Council of Chief State Officers in 1961. The council's policy statement, defining the school library as a part of instruction, is one of the most important publications in creating a favorable attitude toward improving school library services. Mr. Ellsworth has overlooked other important contributions to the description of goals for school library programs. Nowhere does he indicate that he is familiar with the writings of Mary Helen Mahar, nor for example, of the original and significant research of Mary V. Gaver.

Ellsworth begins with an enumeration of the factors which have hastened the recent development of school libraries, following with an analysis of "negative forces" which hindered them. Subsequent chapters deal with the proper role and characteristics of school libraries. The book closes with a short look into the future.

Two sections dealing with censorship give disproportionate weight to this problem. The chapter, "The School Library and Community Relations," except for its opening and closing paragraphs, relates exclusively to censorship. More than half of the final chapter is also concerned with censorship and is out of keeping with the tone and method of the rest of the book. If included at all, the final ten pages should have been an appendix.

As a book for school administrators, The School Library will be valuable in presenting a modern and lively concept of library service for secondary schools. Since it is a part of a subscription series, "The Library of Education," in which individual volumes are not sold separately, it may not, however, reach many of the administrators who most need its message. For school administrators seeking a rationale for elementary school library programs, it will not do at all. A book which encompasses school library services at elementary, junior, and senior high school levels remains to be written.-Richard L. Darling, Montgomery County Public Schools, Maryland.

\section{GOVERNMENT PUBLISHING (Continued from page 489)}

and incomplete printing, publishing, and distribution programs are serious. The problems connected with these programs, while not susceptible to easy or cheap solutions, can be overcome provided vigorous, high-level attention is focussed upon them. In any case, their resolution should not be beyond the capacity of a government which can count the number of chickens in Sagadahoc County and send rockets to the moon.

PROFESSIONAL OR CLERICAL . . (Continued from page 526)

ly complained that their job duties were not adequately represented among the professional items on the questionnaire. In this case it is not reasonable to expect the proportion of professional duties indicated to be a true representation.

In conclusion, the findings of the study seem to verify the results obtained by Griffith and Hart that librarians probably perform more nonprofessional duties than they should.

\section{. . UNIVERSITY ARCHIVES (Continued from page 524)}

chives has been stimulated by the writing of a history of the university. ${ }^{35}$ The archival collection in the university archives is as helpful to the historian as the supplementary nonarchival materials attracted to it.

\footnotetext{
${ }^{35}$ Fulmer Mood and Vernon Carstensen, "University Records and Their Relation to General University Administration," CRL, XI (October 1950), 33940.
} 